\title{
Dynamics and asexual reproduction of the jellyfish Aurelia coerulea benthic life stage in the Thau lagoon (northwestern Mediterranean)
}

\author{
Marques Raquel 5, " , Darnaude Audrey M. 5, Schiariti Agustin ${ }^{2}$, Tremblay Yann ${ }^{1}$, \\ Molinero Juan-Carlos ${ }^{1}$, Soriano Solenn ${ }^{3}$, Hatey Elise ${ }^{5}$, Colantoni Sébastien ${ }^{4}$, Bonnet Delphine ${ }^{4}$
}

\author{
${ }^{1}$ MARBEC, Univ. Montpellier, CNRS, Ifremer, IRD, Montpellier,France \\ 2 INIDEP-IIMyC (CONICET), Mar del Plata, Argentina \\ ${ }^{3}$ Montpellier University, Montpellier,France
}

* Corresponding author : Raquel Marques, email address : raquel.fonseca-da-silva-marques@etu.umontpellier.fr

\begin{abstract}
:
For many jellyfish, the magnitude and timing of medusae blooms are recognized to result from the benthic stage dynamics. However, information on the scyphistomae of jellyfish populations in the wild remains scarce. Here, bi-mensual underwater photoquadrat surveys were combined with scyphistomae sampling and observation to describe the annual (February 2017-January 2018) benthic stage dynamics and asexual reproduction strategy of Aurelia coerulea in the Thau lagoon $\left(43^{\circ} 25^{\prime} 31.1^{\prime \prime} \mathrm{N} ; 03^{\circ} 42^{\prime} 0.9^{\prime \prime} \mathrm{E}\right)$. Our results revealed unexpected seasonal patterns of variation: scyphistoma coverage peaked in the spring $(11.6 \pm 3.7 \%$ on 21 st April) and was minimal in the summer and autumn (1.4 $\pm 1.3 \%$ on 10th October). The increase in scyphistoma coverage mainly resulted from an intense production of buds between February and April during the spring rise in water temperature (peak of 12,800 buds $m-2$ on 21 st April), but scyphistoma coverage appeared to be negatively influenced by the interaction of high summer temperatures and salinities. Strobilation was observed from November to April. It peaked on 17th November, with $33.1 \%$ of the scyphistomae strobilating and an average production of 19,100 strobila disks $m-2$. However, the low scyphistoma coverage at this time of the year $(<2 \%)$ likely limited the intensity of ephyrae liberation and the subsequent medusae bloom. The final population size of $A$. coerulea thus results from a complex interaction of abiotic and biotic factors. Our results bring into question how the different populations of Aurelia spp. will respond to the predicted global warming scenarios.
\end{abstract}




\section{Introduction}

Seeming increases in the frequency of jellyfish blooms in some areas of the world (Richardson et al. 2009; Brotz et al. 2012), together with their negative consequences on several marine or littoral economic activities (Graham et al. 2014), have stimulated the scientific interest on jellyfish ecology and bloom formation.

Climate change, overfishing, eutrophication, introduction of alien species and habitat modifications have all been pointed out as factors that might boost jellyfish blooms (Purcell et al. 2007; Richardson et al. 2009; Purcell 2012; Boero 2013). However, many blooming jellyfish, mostly scyphozoans, have a complex life cycle, which complicates the identification of the factors controlling the magnitude of their blooms. Previous studies suggested that ocean warming might boost jellyfish benthic stage densities by increasing asexual reproduction and scyphistoma survival, especially for temperate species (Purcell 2005, 2012; Purcell et al. 2007; Richardson et al. 2009), which might originate larger and more frequent blooms.

Jellyfish from the Aurelia genus, are among the most common scyphozoans that form blooms (Dawson and Martin 2001; Mills 2001). They are widely distributed in the Mediterranean, where they occur mainly in coastal areas and semi-enclosed seas (Mills 2001). Their life cycle comprises a sexual reproductive pelagic stage and an asexual reproductive benthic stage (hereafter referred as pelagic and benthic populations, respectively). The adult medusae reproduce sexually, releasing planulae which settle on natural and artificial hard substrates (Holst and Jarms 2007; Hoover and Purcell 2009). After settlement, the planulae metamorphose into scyphistomae which can display different asexual reproduction modes, including different budding types (motile and non-motile) and podocysts (see Schiariti et al. 2014 for details). Under specific environmental conditions scyphistomae produce and release great numbers of pelagic ephyrae, through the process of strobilation. These ephyrae grow in the pelagic environment until they reach the adult medusa stage, ultimately causing pelagic population pulses, that can sometimes result in outbreaks or the so-called jellyfish blooms (Schiariti et al. 2014). The timing and magnitude of the Aurelia spp. blooms are therefore dependent on the dynamics of their benthic populations and the environmental factors that control it. Yet, this critical stage of the life cycle has been little investigated so far and very few studies were performed on wild benthic populations of Aurelia spp. (Gröndahl 1988; Willcox et al. 2008; Purcell et al. 2009; Malej et al. 2012; Hocevar et al. 2018). Moreover, the Aurelia genus comprises a complex of species, even within the Mediterranean (Dawson and Jacobs 2001; Dawson and Martin 2001; Scorrano et al. 2016). Among them, Aurelia coerulea has been reported to occur in Japan, China, California, Australia, France and Italy (Dawson et al. 2005; Scorrano et al. 2016). However, information on its wild populations is scarce (Watanabe and Ishii 2001; Miyake et al. 2002; Ishii and Katsukoshi 2010; Makabe et al. 2014). 
The Thau lagoon (NW Mediterranean) presents the rare particularity to harbor a complete resident population of Aurelia coerulea, seemingly isolated from the Mediterranean Sea (Bonnet et al. 2012; Marques et al. 2015a). In this lagoon, ephyrae first appear in the early winter, to give rise to adult individuals at the beginning of spring, when temperature increases (Marques et al. 2015b). Medusae remain in the water column until the late spring, when they reproduce sexually before disappearing from the system. The benthic scyphistomae of $A$. coerulea are found mainly on biofouling organisms covering man-made hard substrates. Their local spatial distribution and preferential habitats in the Thau lagoon have been described thoroughly (Marques et al. 2015a). However, their local seasonal population dynamics and their asexual reproduction strategy are still unexplored.

Changes in jellyfish scyphistoma population size are regulated by the balance between population growth (i.e. the increase in scyphistoma coverage and/or density) and mortality. Population growth might result from the benthic recruitment of planulae, the excystment of podocysts, the production of new scyphistomae by asexual reproduction and the dispersion of detached scyphistomae or motile bud-like tissue particles (Lucas et al. 2012; Schiariti et al. 2015). Scyphistomae mortality might be induced by predation, inter- and intra-specific interactions and physiological stress (Lucas et al. 2012). The influences of varied environmental factors on planulae settlement and scyphistomae asexual reproduction have been studied for several species of the Aurelia genus, mainly in laboratory experiments (e.g. Han and Uye 2010; Purcell et al. 2012; Schiariti et al. 2014; Sokołowski et al. 2016; Hubot et al. 2017). The latter studies suggest that temperature and food availability are likely critical factors controlling benthic population dynamics in Aurelia spp., through an influence on the intensity of scyphistoma asexual reproduction. However, the impacts of biotic and abiotic factors on the wild benthic population dynamics of these jellyfish are complex and still poorly known (Willcox et al. 2008; Malej et al. 2012; Hocevar et al. 2018). Density dependent factors, predation and interspecific space competition were also stressed as important potential drivers of scyphistoma densities, both from in situ (Miyake et al. 2002; Willcox et al. 2008; Feng et al. 2017; Dong et al. 2018) and laboratory studies (Hoover et al. 2012; Takao et al. 2014).

In this context, the present study aimed to (1) describe the seasonal dynamics of the benthic population of $A$. coerulea and its annual asexual reproduction strategy in the Thau lagoon and (2) link it with the annual variation of the main biotic and abiotic factors known to affect jellyfish scyphistoma densities and physiology. This would allow identifying the main drivers of $A$. coerulea scyphistoma population size in this lagoon and the importance of its benthic population dynamics on the timming and intensity of its local pelagic medusae blooms.

\section{Material and Methods}

Study site and sampling 
The Thau lagoon is a semi-enclosed, marine coastal lagoon which covers an area of 75 $\mathrm{km}^{2}$ and is connected to the Mediterranean Sea by three narrow channels (Fig. 1). It is relatively shallow, with mean and maximum depths of 4 and $10 \mathrm{~m}$, respectively (with the exception of a localized depression of $24 \mathrm{~m})$. The monitoring area chosen for this study $\left(43^{\circ} 25^{\prime} 31.1^{\prime \prime} \mathrm{N}\right.$; $03^{\circ} 42^{\prime} 0.9^{\prime \prime} \mathrm{E}$ ) is among those with the biggest shaded continuous surfaces (underside surface of a half-submerged fiberglass boat) and, therefore, highest coverage of A. coerulea scyphistomae in Thau (Marques et al. 2015a). It is located in the eastern part of the lagoon, where the maximum depth is of $7 \mathrm{~m}$. Seasonal changes in the dynamics and asexual reproduction strategy of the scyphistomae of Aurelia coerulea were studied there over one entire year, by 23 SCUBA diving surveys, scheduled every two weeks from February 2017 to January 2018.

\section{Environmental parameters}

For each sampling date, environmental parameters (temperature, salinity, chlorophyll $a$ concentration and mesozooplankton abundance) were monitored. Temperature and salinity were measured with a probe (EC 300 VWR international/ WTW model 350i), right above the scyphistoma monitoring site, at about $0.5 \mathrm{~m}$ depth. Chlorophyll $a$ concentration and mesozooplankton abundance were determined from samples collected at a nearby site (4323'59.1' 'N; 03³6'37.2'’E, Fig. 1). Chlorophyll $a$ concentration was measured from $150 \mathrm{ml}$ water samples, collected in triplicate. Water was filtered on Whatman GF/F filters and stored at $-30^{\circ} \mathrm{C}$ until pigment extraction in acetone and chlorophyll $a$ concentration measurement by spectrofluorimetry (LS 50B Perkin Elmer). Mesozooplankton samples were collected near the surface, by horizontal towing, using a modified WP2 plankton net $(1.2 \mathrm{~m}$ long, $50 \mathrm{~cm}$ opening area and $200-\mu \mathrm{m}$ mesh). Samples were immediately preserved in $4 \%$ buffered formaldehyde until further analysis in the laboratory. Mesozooplankton abundance was determined by visual counting of organisms under dissecting microscope (Olympus SZX7 - ILLT).

\section{Dynamics of the benthic stage}

The temporal dynamics of the benthic stage of A. coerulea on the study site was estimated at a depth of $2-4 \mathrm{~m}$, by measuring the scyphistoma coverage (\%) using an underwater photoquadrat method. For this, four distinct zones of $15 \times 15 \mathrm{~cm}$ (herafter called photoquadrats) were selected on the surface of the wreck, according to four criteria: a minimum distance of $2 \mathrm{~m}$ between photoquadrats and, within each of them, a flat surface area, the absence of large biofouling organisms (e.g. mussels, oysters, sponges, etc.) and the presence of at least a small patch of $A$. coerulea scyphistomae. Their respective positions were identified by scratching the surface of the wreck. Underwater photographs of all four zones were taken at each survey date using a Canon PowerShot G16 camera with Ikelite Canon G16 Compact 
$15 \times 15 \mathrm{~cm}$ was adapted to the camera case in order to keep a constant distance between the camera and the analysed surface. Only the same central square area of $11 \times 11 \mathrm{~cm}\left(121 \mathrm{~cm}^{2}\right)$ was analysed in each photoquadrat to avoid shaded areas. Photographs were pre-treated with Gimp 2.8.22 to improve contrast and analysed using a purpose-built image analysis software in MATLAB (IZS: Image Zone Selector, Tremblay, unpublished). The IZS uses the different colour channels of the images in order to identify, select and determine the percent coverage of the scyphistomae (Fig. 2). All images were also visually inspected and corrections were made when necessary. To avoid the bias linked to software limitations in individual scyphistomae identification, six photographs per photoquadrat, from different times of the year (embracing minimum, maximum and intermediate values of scyphistoma coverage), were re-analysed and scyphistomae were visually counted. The number of scyphistomae in the photographs were plotted against the corresponding value for scyphistoma coverage and a linear regression line was fitted (Fig. 3). The regression equation was used to estimate the number of scyphistomae in all photographs. Scyphistoma densities (in ind $\left.\mathrm{cm}^{-2}\right)$ in each photoquadrat $\left(121 \mathrm{~cm}^{2}\right)$, were then estimated over the entire study period following the equation

(eq.1) Density $=\frac{88.5+6542.1 * \text { Scyphistoma coverage }(\%) * 100^{-1}}{121}$

Where 88.5 and 6542.1 are the $y$-intercept and slope of the regression line, respectevely.

When determining scyphistoma coverage by image analysis, one biofouling species, the red algae Peyssonnelia sp., was identified as an important substrate for scyphistoma fixation, with potential influence on the dynamics of the benthic population of A. coerulea. Therefore, the IZS was also used to assess its coverage (\%), by changing the values of the colour channels. All images were visually inspected and corrected when necessary.

\section{Asexual reproduction strategies}

To investigate the reproductive activity of the benthic population of A. coerulea at each survey date, three samples of scyphistomae, attached to the underside surface of oyster or mussel shells, were collected in the monitoring site. Sampling was done on the same halfsubmerged fiberglass boat, at depths between 2 and $6 \mathrm{~m}$, at few meters away from the photoquadrats. Scyphistomae were brought alive to the laboratory and counted under a dissecting microscope (Olympus SZ40; Olympus KL 1500 LCD), using a small mesh net (mesh $0.65 \mathrm{~cm}^{2}$ ) as a counting grid. Since density dependent effects were previously demonstrated to influence population growth of Aurelia scyphistomae (e.g. Melica et al. 2014; Schiariti et al. 2015), the effect of density was reduced by selecting only the most dense area of each sample for asexual reproduction assessment (i.e. 3 to 22 sections of the counting grid with a mean density of $44.4 \pm 16.6$ scyphistomae $\mathrm{cm}^{-2}$, to obtain a minimum of 100 scyphistomae per sample). Asexual reproduction modes were identified after Schiariti et al. (2014), using needles 
to inspect each individual scyphistoma and recording the following data for each sample: the total number of scyphistomae, their density $\left(\right.$ ind $\mathrm{cm}^{-2}$ ), the percentage of non-reproductive scyphistomae, the percentage of scyphistomae producing non-motile buds (NMB, specifying the percentage of scyphistomae producing 1, 2 or more buds), the number of podocysts per scyphistoma, the percentage of strobilae and the number of disks per strobila. The percentage of scyphistomae producing non-motile buds (NMB) comprises three reproductive modes: typical lateral budding, lateral budding by means of stolons and reproduction from parts of stolons/stalks (see Schiariti et al. 2014 for details). We pooled them since their distinction is often difficult in wild samples and they have an equivalent impact on scyphistomae population dynamics (Schiariti et al. 2014), as they all produce sessile buds right beside the mother scyphistoma and appear to respond to the same environmental clues (Schiariti et al. 2015).

\section{Asexual reproduction effort}

The asexual production $(A P)$ of buds or strobila disks per surface area $\left(\mathrm{m}^{2}\right)$ was estimated for each sampling date $\left(t_{i}\right)$ as:

$$
A P\left(t_{i}\right)=\frac{p * n * d * 10^{3}}{100}
$$

Where $p$ is the percentage of the scyphistomae exhibiting each asexual reproduction strategy (i.e. production of NMB or strobilation), $n$ is the mean number of reproductive outputs (i.e. buds or strobila disks) produced per scyphistoma and $d$ is the mean density of scyphistomae estimated from the four photoquadrats (eq.1). The total number of ephyrae released (ind $\mathrm{m}^{-2}$ ) from the study site during the whole study period (assuming a continuous strobilation period between November and April), was estimated based on Ishii and Katsukoshi (2010) and Makabe et al. (2014). The ephyrae liberation at each sampling date $\left(E L_{t_{i}}\right.$, ind $\left.\mathrm{m}^{-2}\right)$ was calculated as:

$$
\text { (eq.3) }
$$

$$
E L_{t_{i}}=A P\left(t_{i}\right) * R^{-1}
$$

\section{Where $R$ is the residence time of ephyrae (days). $R$ is dependent on temperature $(T)$ and was} estimated based on in situ temperatures in Thau, using the equation obtained by laboratory experiments on A. coerulea from Japan, performed by Makabe et al. (2014), as: (eq.4)

$$
R=109 * e^{-0.221 * T}
$$

The number of ephyrae released (ind $\mathrm{m}^{-2}$ ) from the study site between $t_{0}$ and $t_{l}$ was then estimated as:

(Eq.5)

$$
E L_{1}=\left(E L_{t 0}+E L_{t 1}\right) *\left(t_{1}-t_{0}\right) * 2^{-1}
$$

And that during the whole study period was estimated as:

$$
T E L=E L_{1}+E L_{2}+\cdots+E L_{n}
$$

\section{Statistical analysis}



each reproductive strategy, number of buds and disks produced per scyphistoma and number of podocysts per scyphistoma) differences among sampling months and photoquadrats (for scyphistoma coverage) were tested by one-way ANOVAs, when variables presented normal distribution and homogeneity of variances (tested by Shapiro and Bartlett tests). Otherwise, Kruskal-Wallis tests were used and post hoc tests were carried out using Dunn's test for multiple comparisons. Temporal and spatial autocorrelations were tested by examination of ACF plots and by Mantel tests from ade4 package (Dray and Dufour 2007). Although scyphistoma coverage of $A$. coerulea differed significantly between the four photoquadrats (ANOVA, $F(3,83)=5.33, P=0.002)$, temporal or spatial autocorrelations were not detected so the data from all photoquadrats was grouped for temporal trend analyses. Generalized linear models (GLM, using linear and logistic regressions) were employed to assess the contribution of temperature, salinity, chlorophyll $a$ concentration and mesozooplankton abundance (explanatory variables) on the scyphistoma coverage, NMB and podocysts per scyphistoma (response variables). The minimal adequate model was achieved by a stepwise deletion of the least significant terms from the maximal model, with interactions included. For each fitted model, we calculated AIC and selected the model presenting the lowest AIC. The final models were validated by examination of plots of residuals versus fitted values for the entire model (Harrison et al. 2018). The influence of the environmental parameters on the strobilation activity was assessed by Hurdle models from pscl package (Zeileis et al. 2008), due to the presence of many zeros in the dataset. Spearman correlations tests were used to investigate the relationship between the scyphistoma percent coverage with the NMB and the number of podocysts per scyphistoma. The presence of the red algae was observed in photoquadrats 1,2 and 3. The relationship between scyphistoma and red algae coverages in these three photoquadrats was studied by Pearson correlation test. All statistical analyses were performed using the software $\mathrm{R}$ Studio Version 1.0.143 (R Core Team 2017) and taking $\alpha<0.05$ as the limit for statistical significance.

\section{Results}

\section{Environmental conditions in the Thau lagoon}

The annual pattern of temperature variation in Thau followed the normal trend in temperate regions, with lower values in the winter and higher values in the summer (Fig. 4). During the study period, temperature at the study site ranged from $7.6^{\circ} \mathrm{C}$ (on December $13^{\text {th }}$ 2017 and January $29^{\text {th }} 2018$ ) to $25.8^{\circ} \mathrm{C}$ on June $27^{\text {th }} 2017$. Salinity varied between 35.0 (on

256 February $24^{\text {th }} 2017$ ) to 39.6 (on November $09^{\text {th }} 2017$ ), with a drastic decrease at the end of the

257 study period, where salinity droped to 33.9 (on January $29^{\text {th }} 2018$ ). The concentration of chlorophyll $a$ and the abundance of mesozooplankton were highly variable over the year. 
Chlorophyll $a$ concentration ranged from $0.5 \mu \mathrm{g} \mathrm{L}-1$ (on January $10^{\text {th }} 2018$ ) to $2.8 \mu \mathrm{g} \mathrm{L}^{-1}$ (on

260

261

262

263

264

265

266

267

268

269

270

271

272

273

274

275

276

277

278

279

280

281

282

283

284

285

286

287

288

289

290

291

292

293

294

295

February $24^{\text {th }} 2017$ ) without any clear seasonal pattern, while mesozooplankton abundance varied between 94 and 166607 ind $\mathrm{m}^{-3}$ (on April 21 2017 and June 27 2017 , respectively), with an intermediate peak of abundance at 10524 ind $\mathrm{m}^{-3}$ (on March 10 $0^{\text {th }}$ 2017). Due to logistic constraints, chlorophyll $a$ concentration and mesozooplankton abundance were not measured in August 2017.

\section{Dynamics of the benthic stage}

Scyphistoma coverage in the photoquadrats varied between a minimum of $0.3 \%$ and a maximum of $18 \%$ of the photographed area (both observed in photoquadrat 2, Fig. 5), which corresponds to a range in density of 0.25 to 10.3 scyphistomae $\mathrm{cm}^{-2}$. The overall mean of scyphistoma coverage on the study site fluctuated significantly during the study period (ANOVA, $F(1,21)=11.2, P=0.003)$, with a minimum avarege value $(1.4 \pm 1.3 \%, \mathrm{n}=4)$ on October $10^{\text {th }} 2017$ and a maximum one $(11.6 \pm 3.7 \%, \mathrm{n}=4)$ on April $21^{\text {st }} 2017$. Temporal variations differed slightly among photoquadrats: scyphistoma coverage peaked in April in photoquadrats 1, 3 and 4 and in May - June in photoquadrat 2. However, all photoquadrats presented low scyphistoma coverage between September and November. Scyphistoma coverage for this period was below $1 \%$, with the exception of photoquadrat 4 , where it remained above $3 \%$ during all the study period.

\section{Asexual reproduction strategy}

During the whole study period, the mean percentage of scyphistoma reproducing asexually varied between $2.2 \pm 1.5$ to $33.5 \pm 4.9 \%$ ( $n=3$, per sampling date) (Fig. 6). Scyphistoma-to-scyphistoma reproduction (NMB) was the most important asexual reproduction mode observed. The percentage of scyphistomae producing buds varied between sampling dates (Kruskal-Wallis test, $H 24=53.5, P<0.001$ ). It was maximum between March and May 2017, when $15.0 \pm 6.7$ to $19.4 \pm 5.2 \%$ ( $n=3$, per sampling date) of the scyphistomae were producing buds. The asexual production $\left(A P_{t i}\right)$ of buds was higher in this period, with a peak on the April $21^{\text {st }}$ when 12800 buds $\mathrm{m}^{-2}$ were produced (Fig. 7). The percentage of scyphistomae producing buds was then highly variable until November $(4.6 \pm 1.1$ to $25.2 \pm 7.3 \%, \mathrm{n}=3$, per sampling date), with noticeable peaks above 19\% in July, September and October (Fig. 6). During the study period, most of the budding scyphistomae $(92.8 \pm 17.3 \%, \mathrm{n}=69)$ produced just one bud at a time, but simultaneous production of several buds per scyphistoma was observed all year round (except in January 2018). The maximum number of buds observed for a given scyhistoma (4), was registered in September. However, the production of buds observed per scyphistoma was highest in October: among the budding scyphistoma, $13.7 \pm 5.3 \%(\mathrm{n}=3$, per sampling date) produced two buds and $4.2 \pm 4.5 \%(\mathrm{n}=3$, per sampling date) produced 3 or 
more buds. In November, the percentage of scyphistomae producing buds decreased sharply and reached its lowest value $(0.4 \pm 0.7 \%, \mathrm{n}=3)$ on November $17^{\text {th }}$, when the production of buds was also minimum (70 ind $\mathrm{m}^{-2}$, Fig. 7). This percentage remained low $(<9 \%)$ until the end of the study period (in January 2018).

The average number of podocysts per scyphistoma ranged from 0 to $0.5 \pm 0.4(n=3$, per sampling date), showing high variability between samples from the same date. No significant difference was observed among sampling dates for this reproduction mode (KruskalWallis test, $H 22=24.8, P=0.3)$.

Strobilation was observed from February to April 2017 and from November 2017 to January 2018 suggesting that, ephyrae production by A. coerulea scyphistoma likely occurs from late autumn to early spring in the Thau lagoon (Fig. 6). During this period, the percentage of scyphistomae strobilating varied significantly between sampling dates (Kruskal-Wallis test, $H 24=56.7, P<0.001)$ : less than $5.5 \%$ of the population strobilated irrespective of the month, except in November when this percentage increased to $33.1 \pm 4.2 \%$ ( $n=3$, on November $\left.17^{\text {th }}\right)$. During the strobilation period, the maximum number of disks produced per strobila was of 11 , with a general mean of $3.7 \pm 1.4(n=16)$ disks per scyphistoma. No significant differences between sampling dates were recorded in the number of disks formed per scyphistoma (Kruskal-Wallis test, $H 7=9.9, P=0.2)$. As a result, the estimated asexual production $\left(A P_{t i}\right)$ of strobila disks presented a short but conspicuous peak in November $17^{\text {th }} 2017$ (19 100 disks m$\left.^{-2}\right)$, but was also high in spring, due to high scyphistoma density (Fig. 7). During this season, it peaked at 11800 disks $\mathrm{m}^{-2}$ on February $24^{\text {th }} 2017$ and decreased afterwards to 1500 disks $\mathrm{m}^{-2}$ on April $7^{\text {th }} 2017$, in parallel with an increase of buds production. Assuming a continuous strobilation period between November and April, the total number of ephyrae liberated (TEL) from the study site during the whole study period was estimated at 82301 ind $\mathrm{m}^{-2}$.

\section{Drivers of the dynamics and asexual reproduction}

Scyphistoma coverage was positively influenced by temperature (GLM, $P=0.03$ ) but responded negatively to joint increases in temperature and salinity (GLM, $P=0.03$ ) (Table 1). No significant correlation was found with the other environmental variables tested. The coverage of A. coerulea scyphistomae and that of the red algae (Peyssonnelia sp.) were positively correlated (Pearson correlation, $t 19=5.06, P<0.01$ ).

With regards asexual reproduction modes, scyphistoma coverage was significantly correlated only with the number of podocysts per scyphistoma (Spearman correlation, $S=$ 853.7, $P=0.004$ ), which was similarly affected by temperature (positive correlation, GLM, $P=$ 0.02 ) and by the interaction of temperature and salinity (negative correlation, GLM, $P=0.02$ ) (Table 1). Although NMB was the highest before April, i.e. before the peak of scyphistoma coverage, it was not correlated with the latter variable (Spearman correlation, $S=1746, P=$ 
0.53). Indeed, scyphistoma coverage dropped from spring to summer, while NMB remained high and even peaked when scyphistoma coverage was at its minimum. Moreover, none of the environmental variables tested was significantly correlated with the variability in NMB.

Strobilation intensity was found to be affected only by temperature (Zero Hurdle model, $P=0.046$ ), with the probability of a scyphistoma to strobilate increasing by 0.75 times for each decreasing ${ }^{\circ} \mathrm{C}$ (Table 2). Indeed, the high peak of strobilation observed in November followed a sharp decrease in temperature (of $8.3^{\circ} \mathrm{C}$ ) from October $20^{\text {th }}$ to November $17^{\text {th }}$ (Fig. 4).

\section{Discussion}

\section{Dynamics of the Aurelia coerulea benthic stage}

Extensive patches of Aurelia coerulea scyphistomae cover a variety of anthropogenic submerged substrates in the Thau lagoon (Marques et al. 2015a), which allowed in situ evaluation of the intra-annual dynamics of its population at the benthic stage. Estimated densities in this study varied between 0.25 to 10.3 scyphistomae per $\mathrm{cm}^{-2}$, in accordance with previous estimations for the same species in Japan, of 0.005 to 18 scyphistomae per $\mathrm{cm}^{-2}$ (Miyake et al. 2002; Ishii and Katsukoshi 2010), but also for other species of the Aurelia genus, for which mean densities of $7.3 \pm 0.6$ and $31.3 \pm 1.3$ scyphistomae $\mathrm{cm}^{-2}$ were registered in two sites in Tasmania (Willcox et al. 2008), and of 6 to 27 scyphistomae $\mathrm{cm}^{-2}$ in the Adriatic Sea (Malej et al. 2012; Hocevar et al. 2018). Nonetheless, comparisons among sites are to be considered with caution, because scyphistomae are usually distributed in patches, so the density value changes according to the total area assessed (Miyake et al. 2002) and the substrate type considered. In this study, for instance, scyphistoma density estimates from the photoquadrat survey were much lower than those in the samples used to assess asexual reproduction strategies (9.9 to 78.8 scyphistomae $\mathrm{cm}^{-2}$ ). Still, these latter values are in accordance with those (88 scyphistomae $\mathrm{cm}^{-2}$ ) reported by studies assessing the micro-distribution of scyphistomae on bivalve shells (Miyake et al. 2002).

The intra-annual pattern of demographic variation for A. coerulea scyphistomae in Thau is characterized by a peak in coverage in spring, followed by a decrease until minimum values are reached in the summer and autumn and a progressive recovery over the winter. This trend is not in agreement with previous observations made for A. coerulea (Ishii and Katsukoshi 2010; Makabe et al. 2014) and other Aurelia spp. (e.g. Gröndahl 1988; Willcox et al. 2008; Malej et al. 2012; Hocevar et al. 2018): scyphistomae densities in the Aurelia genus usually peak from spring to summer and are at their lowest in both the autumn and winter months. These differences are surprising because temperature appeared to positively affect the population size of scyphistoma in the wild (Willcox et al. 2008; Hocevar et al. 2018) and this study was conducted in an enclosed coastal habitat with a temperature range $\left(7.6\right.$ to $\left.25.8^{\circ} \mathrm{C}\right)$ similar to those where investigations were made for A. coerulea in Japan $\left(9^{\circ} \mathrm{C}\right.$ to $29^{\circ} \mathrm{C}$, Ishii and 

$27.4^{\circ} \mathrm{C}$, Hocevar et al. 2018). Athough scyphistoma coverage was positively correlated with temperature in Thau, the interaction of high temperatures with high salinities appeared to be detrimental to A. coerulea scyphistoma. Indeed, the salinity range observed in our study site (35.0 to 39.6) was above that reported for the studies conducted in Japan (up to 33, Ishii and Katsukoshi 2010; Makabe et al. 2014), but similar to that reported in the Adriatic (32.8 to ca. 38, Hocevar et al. 2018), where the negative influence of salinity on scyphistoma density was also pointed out. So far, no clear negative effect of salinity was ever found on Aurelia spp. scyphistoma survival (Willcox et al. 2007; Holst and Jarms 2010; Widmer et al. 2016) nor somatic growth (Willcox et al. 2007; Hubot et al. 2017), except when reaching freshwater conditions (Holst and Jarms 2010). However, most laboratory studies so far, focused on the influence of fresh water inputs (e.g. Holst and Jarms 2010; Amorim et al. 2018) and were therefore performed at low salinities $(<37)$ i.e. lower than the values registered in our study, especially in the summer (ca. 39). Still, Hubot et al. (2017) assessed the influence of relatively high salinities on the asexual reproduction and somatic growth of Aurelia coerulea from the Adriatic Sea and reported a decrease in physiological performances between 24 and 37 in salinity. To our knowledge, laboratory experiments on the effect of salinities $>37$ have never been performed with $A$. coerulea but our results suggest that high summer salinity associated with high temperature conditions might be detrimental to its scyphistomae, contributing to the benthic population dynamics observed in the Thau lagoon.

Food availability is often pointed as one of the most important drivers of jellyfish population growth, boosting the production of new scyphistomae (Han and Uye 2010; Schiariti et al. 2014; Ikeda et al. 2017). During this study however, mesozooplankton abundance did not statistically influenced scyphistoma coverage nor NMB. The few existing studies so far on the diet of Aurelia spp. scyphistomae suggested that they feed on microzooplankton (Kamiyama 2011, 2013) and small mesozooplankton species (e.g. copepods, cladocerans, gelatinous zooplankton; Östman 1997). Therefore, only a portion of the potential prey of A. coerulea scyphistomae was surveyed in the present work. To improve our understanding of the influence of food availability on the in situ dynamics of the benthic stage of this species, further investigations on scyphistoma diet associated with micro-, mesozooplankton and epibenthic prey abundance in situ are still required.

Apart from the already discussed impact of temperature and salinity on scyphistoma coverage, other interspecific interactions, such as predation and room for expansion, can also 403 play an important role in reducing the density of jellyfish benthic populations (e.g. Willcox et 404 al. 2008; Takao et al. 2014; Feng et al. 2017). Different species of benthic organisms are able to 405 feed on Aurelia spp. scyphistomae. Some of these predators might even consume more than 600 406 scyphistomae per day (e.g. the crab Hyastenus diacanthus) (Takao et al. 2014). In Thau, several 
potential predators were identified in the photoquadrats (sea stars of the genus Asterina, gasteropods: Ocenebra erinaceus and Hexaplex trunculus, nudibranchs: Felimare villafranca and sea urchins: Paracentrotus lividus), but the consumption of scyphistomae by these organisms has never been reported so far. Fishes feeding on benthic prey might also consume $A$. coerulea scyphistomae, through direct or indirect predation (i.e. targeting their fixation substrate, like bivalves). Their predation pressure might be high enough to significantly affect scyphistomae coverage, as shown in predation experiments involving the sparid Sparus aurata (Marques et al. 2016). The exact importance of predation in controlling the population of $A$. coerulea scyphistomae in the Thau lagoon however remains to be assessed.

Biofouling organisms compete for space with jellyfish scyphistomae, so their densities frequently have negative effects on scyphistoma population growth (Watanabe and Ishii 2001; Willcox et al. 2008; Makabe et al. 2014; Feng et al. 2017). Neverthless, Aurelia spp. appear to be more resilient than other scyphozoans, mainly due to their asexual reproduction modes (Feng et al. 2017, 2018): their scyphistomae can adherate to the surface of different organisms by producing different types of budding, stolons, and can even detach themselves from the substrate and drift to another one (Schiariti et al. 2015). Colonization of other benthic organisms by jellyfish scyphistomae is frequent (Miyake et al. 2002; Willcox et al. 2008; Toyokawa et al. 2011) and even suggested as a promoter of settlement and proliferation for A. coerulea scyphistomae in China (Dong et al. 2018). In Thau, scyphistomae of A. coerulea were recurrently found attached to red algae (Peyssonnelia sp.): in three out of the four photoquadrats surveyed in the present work but also in surrounding areas where scyphistomae were particularly abundant (Marques R., personal observation). The decline of this algae observed in the study site in the summer might have contributed to the concomitant reduction of the benthic population of A. coerulea. These results corroborate the importance of interspecific interactions and settling substrates availability in the population dynamics of Aurelia spp.. Future studies on the in situ demography of the benthic stage of jellyfish should, therefore, be designed to embrace the variability of their settling substrates and the potential role on the population dynamics of certain biofouling organisms that provide adhequate fixation substrate for their scyphistomae.

\section{Contribution of the asexual reproduction}

The growth of jellyfish benthic population, results from both the production of new scyphistomae by asexual reproduction (e.g. via the production of non-motile buds or the excystment of podocysts) and the recruitment of pelagic planulae to the sea floor (Schiariti et al. 2015).

In the Thau lagoon, A. coerulea planulae are usually produced between May and June (Bonnet et al. 2012), when they swim to the bottom and settle on the substrate. Pelagic life 
duration before settlement is usually short (typically less than 4 days, Lucas et al. 2012), probably to decrease planulae vulnerability to predation in the pelagic environment (Lucas et al. 2012). Thus, we expected an increase of scyphistoma coverage after planulae release in 2017 , which was not detected. Instead, scyphistoma coverage started to decrease in May 2017, when the first medusae with planulae about to be released were spotted in the lagoon (Marques R., personal observation). Therefore, the recruitment of new scyphistomae by planulae fixation does not contribute most to the observed benthic population dynamics, at least at our study site. In Aurelia spp., planulae are thought to play an important role in the expansion of populations to new habitats through pelagic dispersion (Holst and Jarms 2007; Lucas et al. 2012). This is probably the case in Thau, where the presence of A. coerulea scyphistomae over the entire lagoon area might result from the dissimination of planulae, together with the widespread availability of suitable settling substrates and favourable hydrographic caracteristics in the lagoon (Marques et al. 2015a).

Although podocysts excystment was suggested to play an important role in bloom formation for some jellyfish species (e.g. Nemopilema nomurai; Kawahara et al. 2013), its impact on scyphistoma density was very limited in the population of $A$. coerulea investigated so far (e.g. Thein et al. 2012). In this species, podocysts appear to lie in ensuring the survival of the benthic population under unfavourable conditions and providing protection from predators (Arai 2009; Thein et al. 2012; Hubot et al. 2017). In our study, the number of podocysts per scyphistoma was significantly correlated with scyphistoma coverage and it appears to follow the same environmental forcing, which may suggest a significant contribution of podocysts for the increasing of the benthic stage. Nevertheless, until the exact production, excystment and residency time are assessed for the species in the wild, it is impossible to tell wether there were more scyphistomae at our study site because more podocysts were produced or vice-versa. For this reason, the significance of the contribution of podocysts excystment to the increase of scyphistoma coverage of $A$. coerulea in Thau remains elusive.

The production of $\mathrm{NMB}$, on the contrary, could be the main responsible for local increases of scyphistoma coverage. Although the temporal trend of NMB and scyphistoma coverage were not significantly correlated (with a mismatch during the summer), a high percentage of scyphistomae produced buds in March and April. Estimates for bud production intensity on the study site matched the peak of scyphistoma coverage, supporting the hypothesis that the bud production is the main asexual mode responsible for benthic population increases in Thau. During the end of spring and beginning of summer, both NMB and scyphistoma coverage decrease, but more than $10 \%$ of the scyphistomae produced continuously at least one bud per scyphistoma, and it even peaked in September, when scyphistoma coverage was very low.

479 Although in laboratory experiments, the production of buds is boosted by high temperatures and 
2017), none of the environmental variables tested were significantly correlated with NMB at our

482

483

484

485

486

487

488

489

490

491

492

493

494

495

496

497

498

499

500

501

502

503

504

505

506

507

508

509

510

511

512

513

514

515

516

517 study site. Still, we suspect that high salinities in Thau lagoon during the summer might be unfavourable to the production of buds, as demonstrated by Purcell (2007) and Hubot et al. (2017). However, additional information on the intraannual availability of scyphistoma prey in the lagoon, together with a long-term survey, is needed to reach a more complete understanding of the drivers of this asexual reproduction mode followed by A. coerulea in the Thau lagoon.

\section{Strobilation}

In Thau, the strobilation period for A. coerulea appears to span from the end of the autumn (November) and the beginning of the spring (April), with a peak in November (33\% of the population strobilated in November 2017). This result is in accordance with the previously reported period for ephyrae presence in the lagoon, from early winter to early spring (Marques et al. 2015b), and with the strobilation periods described so far in other areas for A. coerulea (Toyokawa et al. 2000; Watanabe and Ishii 2001; Miyake et al. 2002; Uye and Shimauchi 2005) and for A. aurita (Hocevar et al. 2018). As previously suggested by Holst (2012), the strobilation onset in our study seems to have been triggered by a sharp drop (of $8.3^{\circ} \mathrm{C}$ ) in water temperature, as temperatures in Thau fell to $10^{\circ} \mathrm{C}$ over a few days in November 2017. Water temperatures below $15^{\circ} \mathrm{C}$ have been shown to induce physiological changes in the scyphistomae of A. coerulea, probably to prepare them for metamorphosis (Han and Uye 2010; Feng et al. 2018). This is possibly what happened in the A. coerulea scyphistomae of Thau in November 2017.

The magnitude of most jellyfish blooms is tightly reliant on the density of scyphistomae, but also on their strobilation strategy as this later directly determines the magnitude of the initial production of the pelagic individuals responsible for the blooms. The number of ephyrae released depends on the number of disks produced per strobila combined with the number of strobilating scyphistomae. In Thau, an average of $3.7 \pm 1.4$ disks per scyphistoma were produced by A. coerulea over the strobilation period, which is in accordance with previous observations (3.2 - 7.7 disks per scyphistoma) made for Aurelia spp. (Holst 2012; Makabe et al. 2014; Feng et al. 2018). Despite the low percentage of scyphistomae strobilating in February $(<5.5 \%)$ the estimated production of disks was relatively high (11 800 disks per $\mathrm{m}^{2}$ ), due to the high density of scyphistomae at this time of the year (>30000 ind per $\left.\mathrm{m}^{2}\right)$. However, the main period of A. coerulea strobilation was observed in November with a production of circa 19100 disks per $\mathrm{m}^{2}$. If our study was representative of a complete strobilation season (i.e. from November to April in the same year), the number of ephyrae released (of 82301 ephyrae per $\mathrm{m}^{2}$ ), at our study site would be much higher than previous estimations for A. coerulea in Japan (131 ephyrae per $\mathrm{m}^{2}$ ) by Ishii and Katsukoshi (2010), but close to that (86 806 ephyrae $\mathrm{m}^{-2}$ ) from Makabe et al. (2014). This production, though, was 
518 limited by the low densities of scyphistomae in this season, especially in November. Therefore,

519 the magnitude of A. coerulea blooms in Thau is limited, not only by the mortality of ephyrae

520 during the winter (Fu et al. 2014), but also by the important mortality of scyphistomae over the

521 summer.

522

\section{Conclusion}

524 While climate change and the consequent ocean warming are currently expected to

525 cause larger and more frequent jellyfish blooms, our results prompt the question if all

526 populations of one of the most blooming genus, the Aurelia, will respond likewise. In this

527 temperate lagoon the seasonal dynamics of the benthic stage of A. coerulea in 2017 contrasted

528 those previously described for Aurelia genus, mainly because of a combination of high

529 temperatures and salinities in the summer that appear to be detrimental to scyphistomae of $A$.

530 coerulea. The resulting decrease in scyphistomae density undoubtedly reduced the outcome of

531 the late-autumn strobilation peak in Thau, thereby limiting the intensity of the subsequent

532 pelagic bloom of $A$. coerulea. Because warm and dry summers are expected to be more

533 frequent in the coming decades in the Mediterranean area (IPCC 2014), we may assist to a

534 decrease in the benthic population size and in the intensity of the blooms of this jellyfish, at

535 least in Thau. However, the short-term of this study hampers substantiated conclusions and

536 further investigations, based on long-term studies, are still required to corroborate such

537 suspicion.

538 Consequently, there is an urgent need for widespread in situ studies on the benthic

539 population dynamics of scyphozoans and their local environmental drivers. In jellyfish, benthic

540 population dynamics is an outcome of complex biotic and abiotic interactions which apparently

541 act differently in each ecosystem. Our results show that predicting it needs comprehensive

542 understanding of the interspecific relationships that might regulate scyphistoma abundance.

543 Long-term in situ studies, involving different species of jellyfish and encompassing diverse

544 localities and habitats are crucial if we want to understand the formation of jellyfish blooms and

545 their fate in the face of the predicted climate change. 


\section{Compliance with Ethical Standards}

547 Conflict of interest: The authors declare that they have no conflict of interest.

548 Ethical approval: All applicable international, national, and/or institutional guidelines for the

549 care and use of animals were followed. The jellyfish Aurelia coerulea is an invertebrate which

550 is not endangered or protected species and therefore, no permits were needed for sampling their

551 scyphistomae. All bivalves with attached scyphistomae were released alive after laboratory

552 observation.

553

554 Acknowledgment:

555 We thank Nicholas Nouguier and Remy Valdes for their technical support and expertise during

556 SCUBA dives and field work. Chlorophyll $a$ and mesozooplankton data are part of a long-term

557 monitoring programme on microbial communities in Thau lagoon funded by Observatoire des

558 Sciences de l'Univers OREME (OSU-OREME). Data are available on (http://www.oreme.univ-

559 montp2.fr/). We also thank the anonymous reviewers and the handling editor for valuable

560 comments on this paper.

561 


\section{References:}

Amorim K, Mattmüller RM, Algueró-Muñiz M, Meunier CL, Alvarez-Fernandez S, Boersma M, Morais P, Teodósio MA (2018) Winter river discharge may affect summer estuarine jellyfish blooms. Mar Ecol Prog Ser 591:253-265.

Arai MN (2009) The potential importance of podocysts to the formation of scyphozoan blooms: A review. Hydrobiologia 616:241-246. doi: 10.1007/s10750-008-9588-5

Boero F (2013) Review of jellyfish blooms in the Mediterranean and Black Sea. Rome

Bonnet D, Molinero J-C, Schohn T, Daly-Yahia MN (2012) Seasonal changes in the population dynamics of Aurelia aurita in Thau lagoon. Cah Biol Mar 53:343-347.

Brotz L, Cheung WWL, Kleisner K, Pakhomov E, Pauly D (2012) Increasing jellyfish populations: Trends in Large Marine Ecosystems. Hydrobiologia 690:3-20. doi: 10.1007/s10750-012-1039-7

Dawson MN, Jacobs DK (2001) Molecular evidence for cryptic species of Aurelia aurita (Cnidaria, Schyphozoa). Biol Bull 200:92-96. doi: 10.3102/00346543067001043

Dawson MN, Martin DL (2001) Geographic variation and ecological adaptation in Aurelia aurita (Scyphozoa, Semaestomeae): some implications from molecular phylogenetics. Hydrobiologia 451:259-273.

Dawson MN, Gupta A Sen, England MH (2005) Coupled biophysical global ocean model and molecular genetic analyses identify multiple introductions of cryptogenic species. Pnas 102:11968-11973. doi: 10.1073/pnas.0503811102

Dong Z, Sun T, Wang L (2018) The biogenic reefs formed by the alien polychaete Hydroides dianthus (Serpulidae, Annelida) favor the polyp stage of Aurelia coerulea (Cnidaria, Scyphozoa) in a coastal artificial lake. Mar Pollut Bull 129:86-91. doi: 10.1016/j.marpolbul.2018.02.016

Dray S, Dufour A (2007) The ade4 Package: Implementing the Duality Diagram for Ecologists. Feng S, Wang SW, Zhang GT, Sun S, Zhang F (2017) Selective suppression of in situ proliferation of scyphozoan polyps by biofouling. Mar Pollut Bull 114:1046-1056. doi: 10.1016/j.marpolbul.2016.10.062

Feng S, Wang SW, Sun S, Zhang F, Zhang GT, Liu MT, Uye SI (2018) Strobilation of three scyphozoans (Aurelia coelurea, Nemopilema nomurai, and Rhopilema esculentum) in the field at Jiaozhou Bay, China. Mar Ecol Prog Ser 591:141-153. doi: 10.3354/meps12276

Fu Z, Shibata M, Makabe R, Ikeda H, Uye SI (2014) Body size reduction under starvation, and the point of no return, in ephyrae of the moon jellyfish Aurelia aurita. Mar Ecol Prog Ser 510:255-263. doi: 10.3354/meps10799

Graham WM, Gelcich S, Robinson KL, Duarte CM, Brotz L, Purcell JE, Madin LP, Mianzan H, Sutherland KR, Uye SI, Pitt KA, Lucas CH, Bøgeberg M, Brodeur RD, Condon RH (2014) Linking human well-being and jellyfish: Ecosystem services, impacts, and societal 
Gröndahl F (1988) A comparative ecological study on the scyphozoans Aurelia aurita, Cyanea

601

602

603

604

605

606

607

608

609

610

611

612

613

614

615

616

617

618

619

620

621

622

623

624

625

626

627

628

629

630

631

632

633

634

635 capillata and C. lamarckii in the Gullmar Fjord, western Sweden, 1982 to 1986. Mar Biol 97:541-550. doi: 10.1007/BF00391050

Han C-H, Uye S-I (2010) Combined effects of food supply and temperature on asexual reproduction and somatic growth of polyps of the common jellyfish Aurelia aurita s.l. Plankt Benthos Res 5:98-105. doi: 10.3800/pbr.5.98

Harrison XA, Donaldson L, Correa-cano ME, Evans J, Fisher DN, Goodwin CED, Robinson BS, Hodgson DJ, Inger R (2018) A brief introduction to mixed effects modelling and multi-model inference in ecology. PeerJ 6:e4794:1-32. doi: 10.7717/peerj.4794

Hocevar S, Malej A, Boldin B, Purcell JE (2018) Seasonal fluctuations in population dynamics of Aurelia aurita polyps in situ with a modelling perspective. Mar Ecol Prog Ser 591:155166. doi: 10.3354/meps 12387

Holst S (2012) Effects of climate warming on strobilation and ephyra production of North Sea scyphozoan jellyfish. Hydrobiologia 690:127-140. doi: 10.1007/s10750-012-1043-y

Holst S, Jarms G (2007) Substrate choice and settlement preferences of planula larvae of five Scyphozoa (Cnidaria) from German Bight, North Sea. Mar Biol 151:863-871. doi:

$$
\text { 10.1007/s00227-006-0530-y }
$$

Holst S, Jarms G (2010) Effects of low salinity on settlement and strobilation of scyphozoa (Cnidaria): Is the lion's mane Cyanea capillata (L.) able to reproduce in the brackish Baltic Sea? Hydrobiologia 645:53-68. doi: 10.1007/s10750-010-0214-y

Hoover RA, Purcell JE (2009) Substrate preferences of scyphozoan Aurelia labiata polyps among common dock-building materials. Hydrobiologia 616:259-267. doi: 10.1007/s10750-008-9595-6

Hoover RA, Armour R, Dow I, Purcell JE (2012) Nudibranch predation and dietary preference for the polyps of Aurelia labiata (Cnidaria: Scyphozoa). Hydrobiologia 690:199-213. doi: 10.1007/s10750-012-1044-x

Hubot N, Lucas CH, Piraino S (2017) Environmental control of asexual reproduction and somatic growth of Aurelia spp. (Cnidaria, Scyphozoa) polyps from the Adriatic Sea. PLoS One. doi: 10.1371/journal.pone.0178482

Ikeda H, Mizota C, Uye S (2017) Bioenergetic characterization in Aurelia aurita ( Cnidaria : Scyphozoa ) polyps and application to natural polyp populations. 568:87-100.

IPCC (2014) Climate Change 2014 Synthesis Report. Contribution of Working Groups I, II and III to the Fifth Assessment Report of the Intergovernmental Panel on Climate Change. IPCC, Geneva

Ishii H, Katsukoshi K (2010) Seasonal and vertical distribution of Aurelia aurita polyps on a pylon in the innermost part of Tokyo Bay. J Oceanogr 66:329-336. doi: 10.1007/s10872- 
010-0029-5

Kamiyama T (2011) Planktonic ciliates as a food source for the scyphozoan Aurelia aurita (s.1.): Feeding activity and assimilation of the polyp stage. J Exp Mar Bio Ecol 407:207215. doi: 10.1016/j.jembe.2011.06.016

Kamiyama T (2013) Planktonic ciliates as food for the scyphozoan Aurelia aurita (s.1.): Effects on asexual reproduction of the polyp stage. J Exp Mar Bio Ecol 445:21-28. doi: 10.1016/j.jembe.2013.03.018

Kawahara M, Ohtsu K, Uye SI (2013) Bloom or non-bloom in the giant jellyfish Nemopilema nomurai (Scyphozoa: Rhizostomeae): Roles of dormant podocysts. J Plankton Res 35:213-217. doi: 10.1093/plankt/fbs074

Lucas CH, Graham WM, Widmer C (2012) Jellyfish Life Histories: Role of Polyps in Forming and Maintaining Scyphomedusa Populations, 1st edn. Elsevier Ltd.

Makabe R, Furukawa R, Takao M, Uye SI (2014) Marine artificial structures as amplifiers of Aurelia aurita s.l. blooms: A case study of a newly installed floating pier. J Oceanogr 70:447-455. doi: 10.1007/s10872-014-0249-1

Malej A, Kogovšek T, Ramšak A, Catenacci L (2012) Blooms and population dynamics of moon jellyfish in the northern Adriatic Blooms and population dynamics of moon jellyfish in the northern Adriatic. Cah Biol Mar 53:337-342.

Marques R, Cantou M, Soriano S, Molinero JC, Bonnet D (2015a) Mapping distribution and habitats of Aurelia sp. Polyps in Thau lagoon, north-western Mediterranean sea (France). Mar Biol 162:1441-1449. doi: 10.1007/s00227-015-2680-2

Marques R, Albouy-Boyer S, Delpy F, Carré C, Le Floc'R É, Roques C, Molinero JC, Bonnet D (2015b) Pelagic population dynamics of Aurelia sp. in French Mediterranean lagoons. J Plankton Res 37:1019-1035. doi: 10.1093/plankt/fbv059

Marques R, Bouvier C, Darnaude AM, Molinero J-C, Przybyla C, Soriano S, Tomasini J-A, Bonnet D (2016) Jellyfish as an alternative source of food for opportunistic fishes. J Exp Mar Bio Ecol. doi: 10.1016/j.jembe.2016.08.008

Melica V, Invernizzi S, Caristi G (2014) Logistic density-dependent growth of an Aurelia aurita polyps population. Ecol Modell 291:1-5. doi: 10.1016/j.ecolmodel.2014.07.009

Mills C (2001) Are population increasing globally in reponse to changing ocean conditions? Hydrobiologia 451:55-68.

Miyake H, Terazaki M, Kakinuma Y (2002) On the polyps of the common jellyfish Aurelia aurita in Kagoshima Bay. J Oceanogr 58:451-459. doi: 10.1023/A:1021628314041

Östman C (1997) Abundance, feeding behaviour and nematocysts of scyphopolyps (Cnidaria) and nematocysts in their predator, the nudibranch Coryphella verrucosa (Mollusca). In: Naumov AD, Hummel H, Sukhotin AA, Ryland JS (eds) Interactions and Adaptation Strategies of Marine Organisms. Developments in Hydrobiology, vol 121. Springer, 
Purcell JE (2005) Climate effects on formation of jellyfish and ctenophore blooms: a review. J Mar Biol Assoc UK 85:461-476. doi: 10.1017/S0025315405011409

Purcell JE (2007) Environmental effects on asexual reproduction rates of the scyphozoan Aurelia labiata. Mar Ecol Prog Ser 348:183-196. doi: 10.3354/meps07056

Purcell JE (2012) Jellyfish and Ctenophore Blooms Coincide with Human Proliferations and Environmental Perturbations. Ann Rev Mar Sci 4:209-235. doi: 10.1146/annurev-marine120709-142751

Purcell JE, Uye SI, Lo WT (2007) Anthropogenic causes of jellyfish blooms and their direct consequences for humans: A review. Mar Ecol Prog Ser 350:153-174. doi: 10.3354/meps07093

Purcell JE, Hoover RA, Schwarck NT (2009) Interannual variation of strobilation by the scyphozoan Aurelia labiata in relation to polyp density, temperature, salinity, and light conditions in situ. Mar Ecol Prog Ser 375:139-149. doi: 10.3354/meps07785

Purcell JE, Atienza D, Fuentes V, Olariaga A, Tilves U, Colahan C, Gili JM (2012) Temperature effects on asexual reproduction rates of scyphozoan species from the northwest Mediterranean Sea. Hydrobiologia 690:169-180. doi: 10.1007/s10750-012$1047-7$

R Core Team (2017) R: A language and environment for statistical computing.

Richardson AJ, Bakun A, Hays GC, Gibbons MJ (2009) The jellyfish joyride: causes, consequences and management responses to a more gelatinous future. Trends Ecol Evol 24:312-322. doi: 10.1016/j.tree.2009.01.010

Schiariti A, Morandini AC, Jarms G, Von Glehn Paes R, Franke S, Mianzan H (2014) Asexual reproduction strategies and blooming potential in Scyphozoa. Mar Ecol Prog Ser 510:241253. doi: $10.3354 /$ meps 10798

Schiariti A, Melica V, Kogovšek T, Malej A (2015) Density-dependent effects control the reproductive strategy and population growth of Aurelia aurita s.l. scyphistomae. Mar Biol 162:1665-1672. doi: 10.1007/s00227-015-2704-y

Scorrano S, Aglieri G, Boero F, Dawson MN, Piraino S (2016) Unmasking Aurelia species in the Mediterranean Sea: An integrative morphometric and molecular approach. Zool J Linn Soc. doi: 10.1111/zoj.12494

Sokołowski A, Brulińska D, Olenycz M, Wołowicz M (2016) Does temperature and salinity limit asexual reproduction of Aurelia aurita polyps (Cnidaria: Scyphozoa) in the Gulf of Gdańsk (southern Baltic Sea)? An experimental study. Hydrobiologia 773:49-62. doi: 10.1007/s10750-016-2678-x

Takao M, Okawachi H, Uye S (2014) Natural predators of polyps of Aurelia aurita s.l. (Cnidaria: Scyphozoa: Semaeostomeae) and their predation rates. Plankt Benthos Res 
9:105-113. doi: 10.3800/pbr.9.105

Thein H, Ikeda H, Uye S ichi (2012) The potential role of podocysts in perpetuation of the common jellyfish Aurelia aurita s.l. (Cnidaria: Scyphozoa) in anthropogenically perturbed coastal waters. Hydrobiologia 690:157-167. doi: 10.1007/s10750-012-1045-9

Toyokawa M, Aoki K, Yamada S, Yasuda A, Murata Y, Kikuchi T (2011) Distribution of ephyrae and polyps of jellyfish Aurelia aurita (Linnaeus 1758) sensu lato in Mikawa Bay, Japan. J Oceanogr 67:209-218. doi: 10.1007/s10872-011-0021-8

Toyokawa1 M, Furota2 T, Terazaki3 M (2000) Life history and seasonal abundance of Aurelia aurita medusae in Tokyo Bay, Japan. Plankt Biol Ecol 47:48-58.

Uye S, Shimauchi H (2005) Population biomass, feeding, respiration and growth rates, and carbon budget of the scyphomedusa Aurelia aurita in the Inland Sea of Japan. J Plankton Res 27:237-248. doi: 10.1093/plankt/fbh172

Watanabe T, Ishii H (2001) In situ estimation of ephyrae liberated from polyps of Aurelia aurita using settling plates in Tokyo Bay, Japan. Hydrobiologia 451:247-258. doi: 10.1023/A:1011856929443

Widmer CL, Fox CJ, Brierley AS (2016) Effects of temperature and salinity on four species of northeastern Atlantic scyphistomae (Cnidaria: Scyphozoa). Mar Ecol Prog Ser 559:73-88. doi: $10.3354 /$ meps 11879

Willcox S, Moltschaniwskyj NA, Crawford C (2007) Asexual reproduction in scyphistomae of Aurelia sp.: Effects of temperature and salinity in an experimental study. J Exp Mar Bio Ecol 353:107-114. doi: 10.1016/j.jembe.2007.09.006

Willcox S, Moltschaniwskyj NA, Crawford CM (2008) Population dynamics of natural colonies of Aurelia sp. scyphistomae in Tasmania, Australia. Mar Biol 154:661-670. doi: 10.1007/s00227-008-0959-2

Zeileis A, Kleiber C, Jackman S (2008) Regression Models for Count Data in R. J Stat Softw 27:1-25. doi: 10.18637/jss.v027.i08 


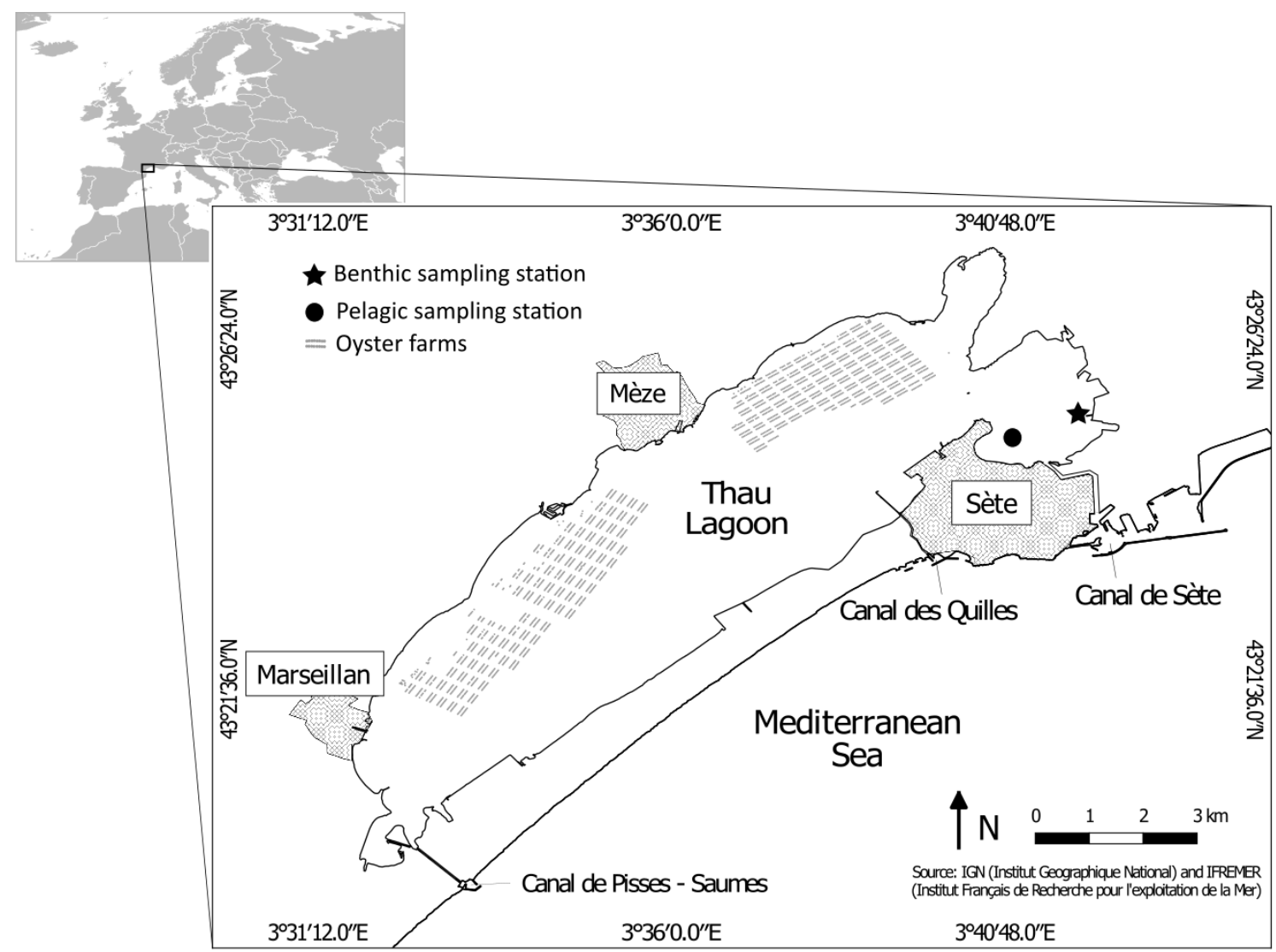

740

741 Fig. 1 Map of the Thau lagoon showing the location of the benthic (star) and pelagic (circle) sampling sites for this study. Shaded areas represent urban areas 

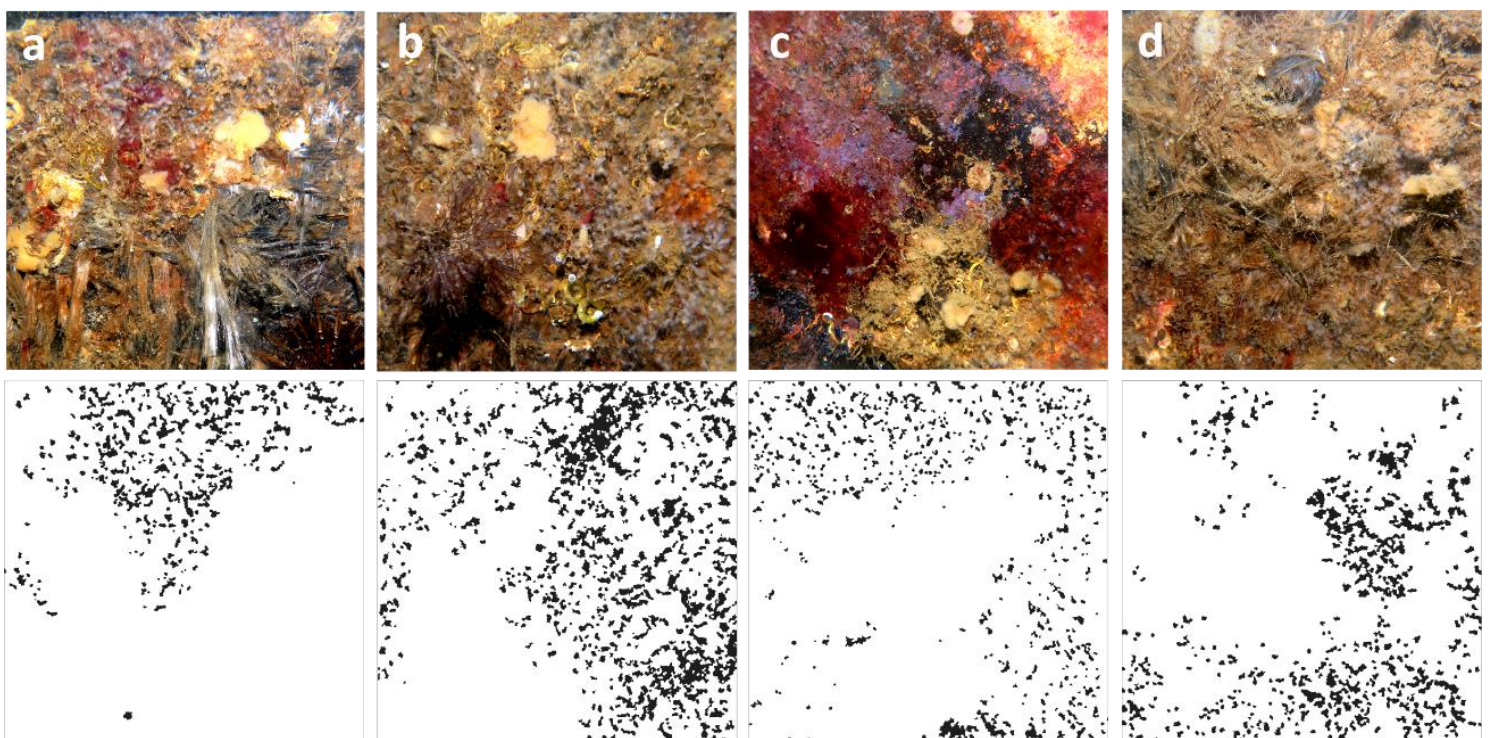

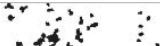

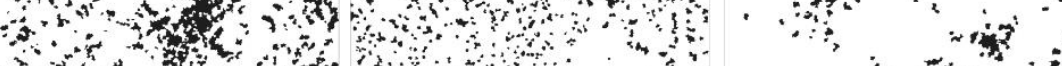
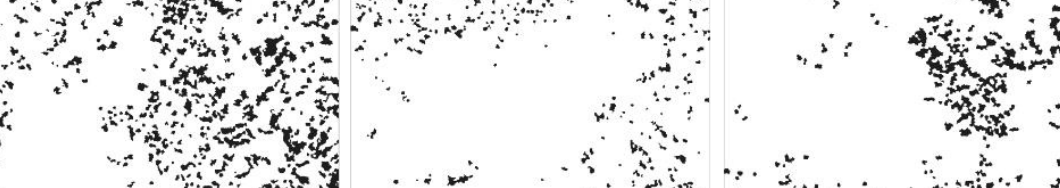

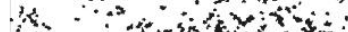
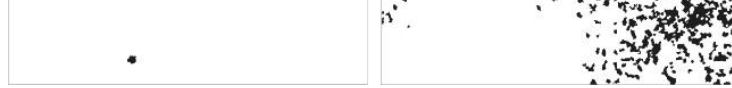

and 2 a

745 Fig. 2 Example of the photoquadrats (top) and the respective IZS output (bottom). a)

746 photoquadrat $1(6.10 \%$ coverage $), b)$ photoquadrat $2(16.1 \%$ coverage $), c)$ photoquadrat 3

747 (6.64 \% coverage), c) photoquadrat 4 (9.93\% coverage). 


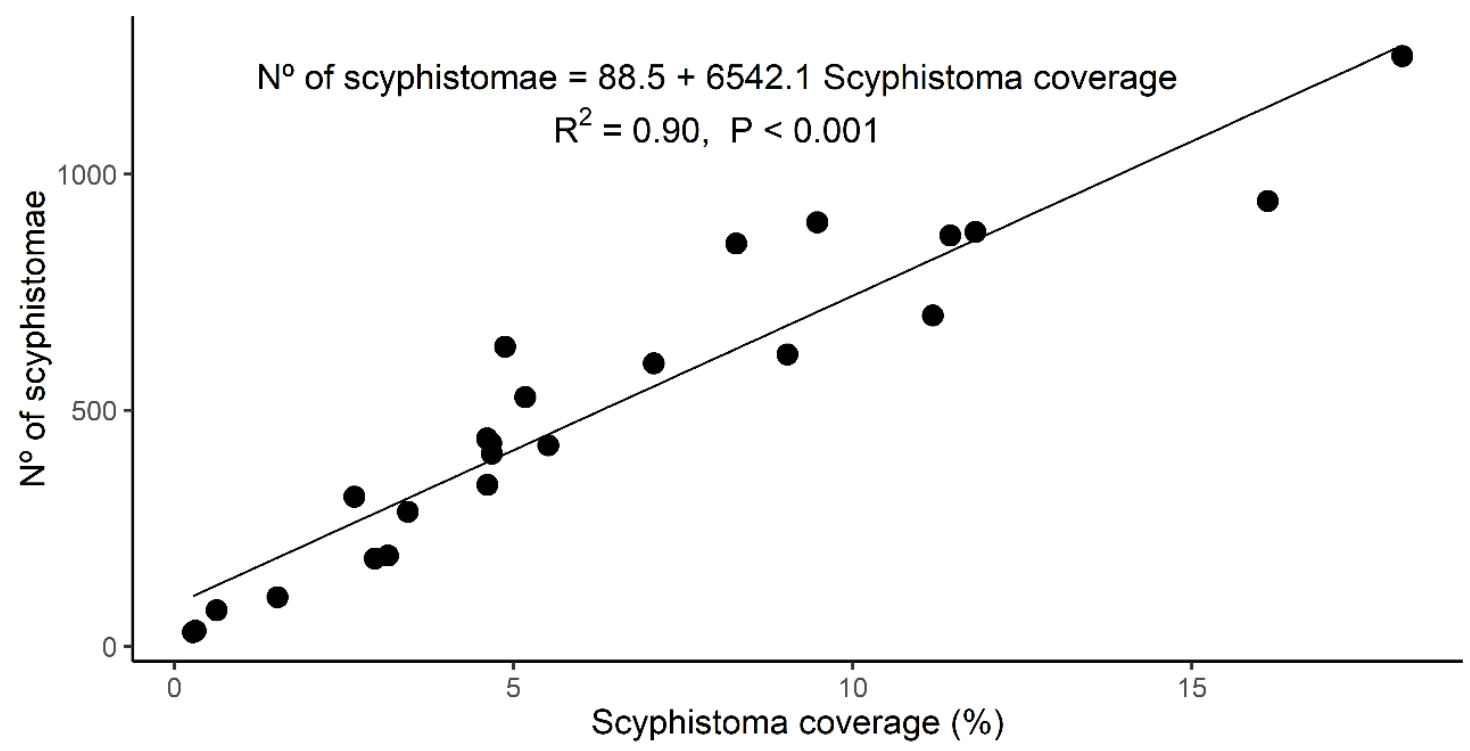

749

750 Fig. 3 Relationship between number of scyphistomae and scyphistoma coverage (\%) in the

751 photoquadrats $\left(121 \mathrm{~cm}^{-2}\right)$. The resulting equation was used to estimate scyphistoma density in

752 the study site (eq. 1)

753 

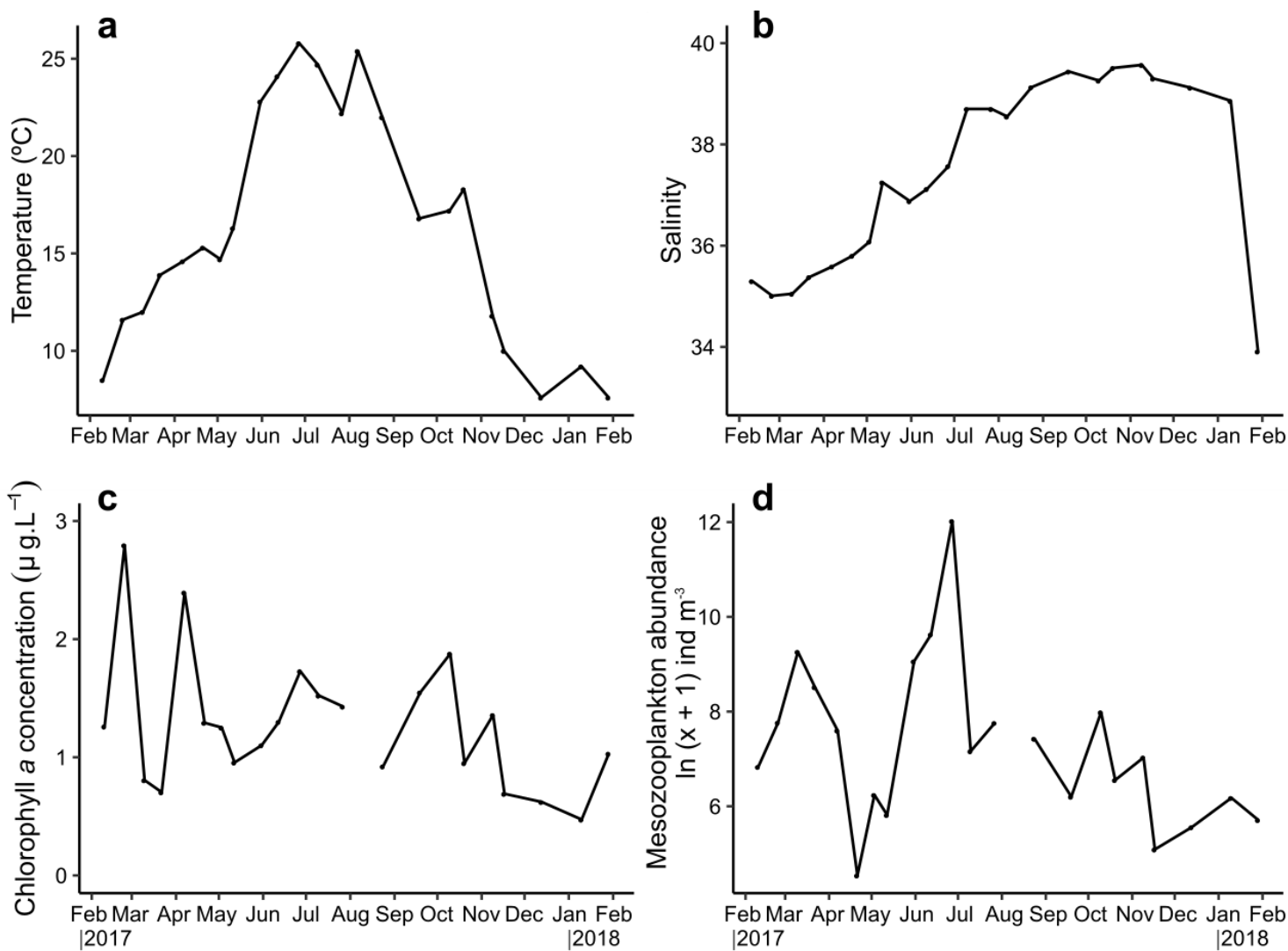

755

756 Fig. 4 Variation of the environmental variables in the Thau lagoon, during the study period: a) 


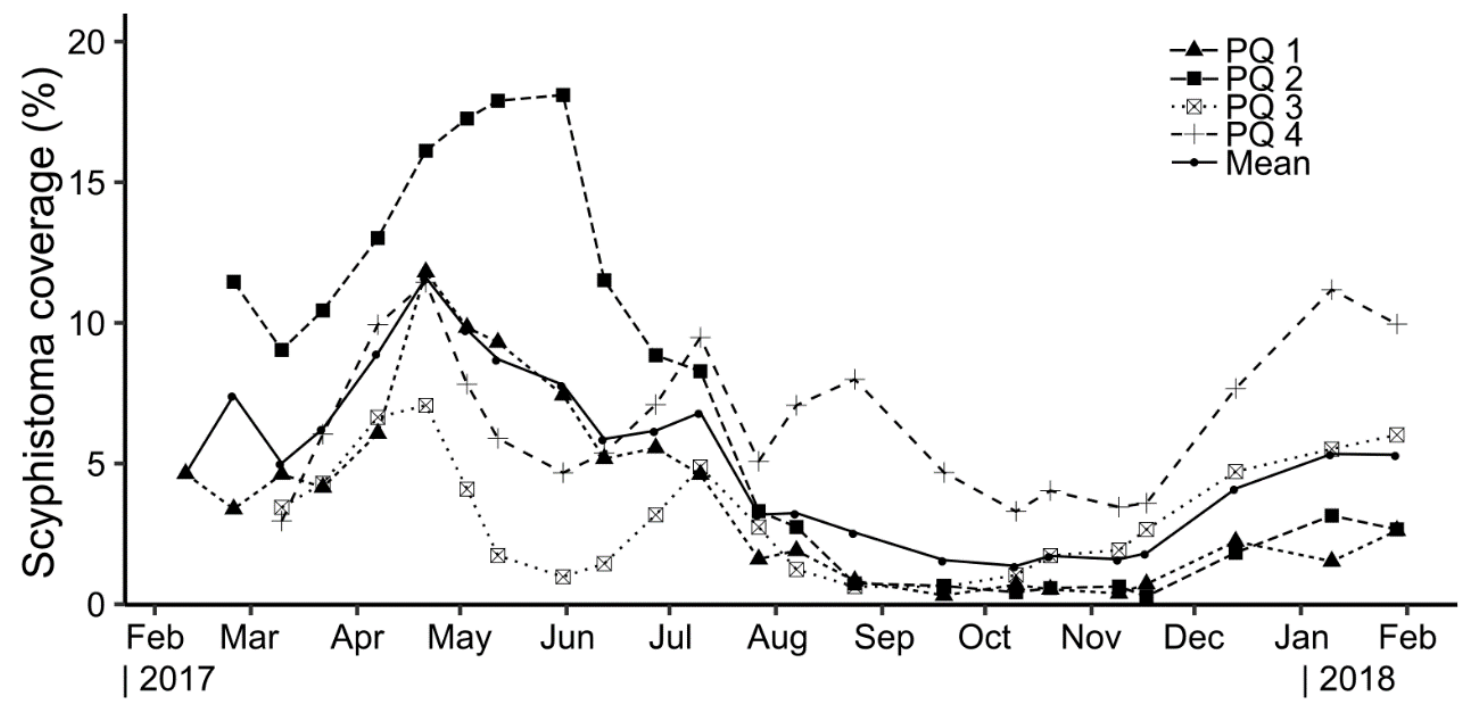

760

761 Fig. 5 Variation of A. coerulea scyphistoma coverage in each photoquadrats (PQ) and the mean 762 of all photoquadrats, during the study period 


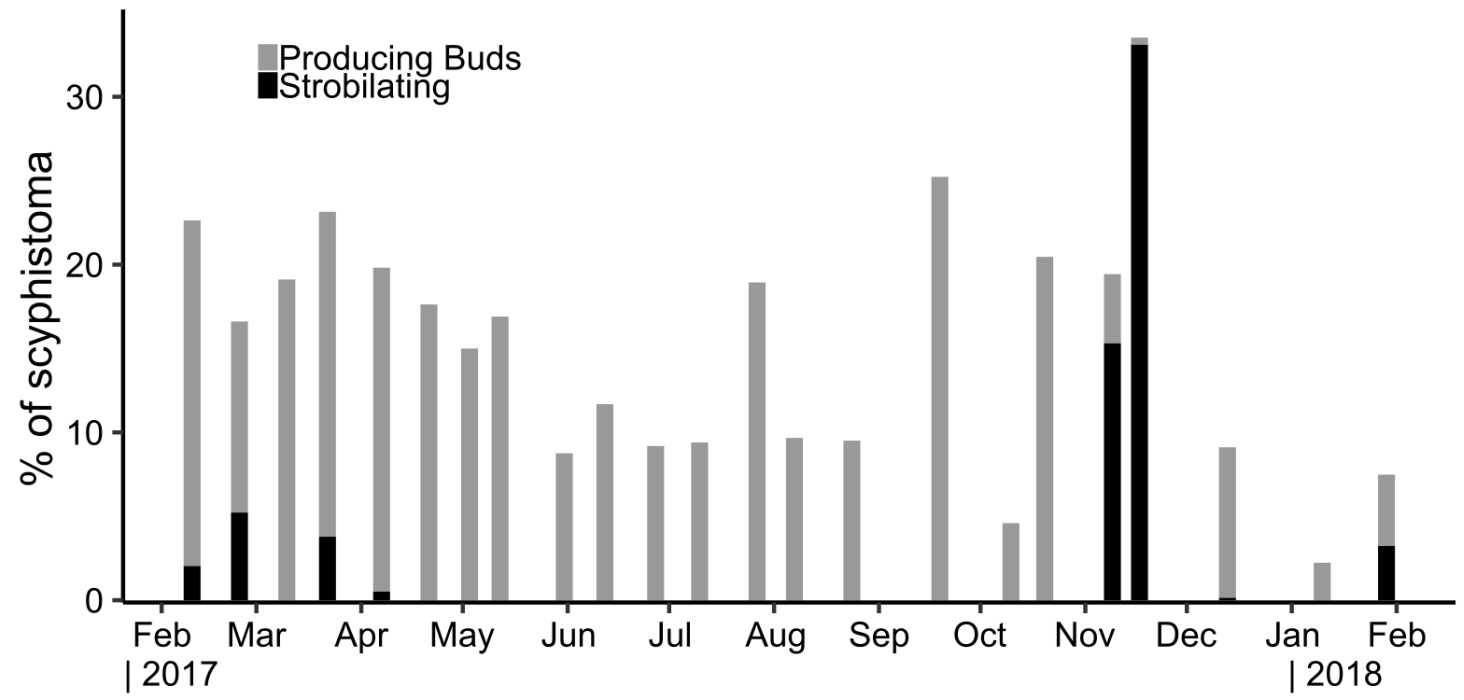

765

766 Fig. 6 Annual asexual reproduction strategy of A. coerulea scyphistoma in the Thau lagoon over

767 the study period. Each bar represents the percentage of the population producing non-motile buds (grey) and strobilating (black) at each sampling time 


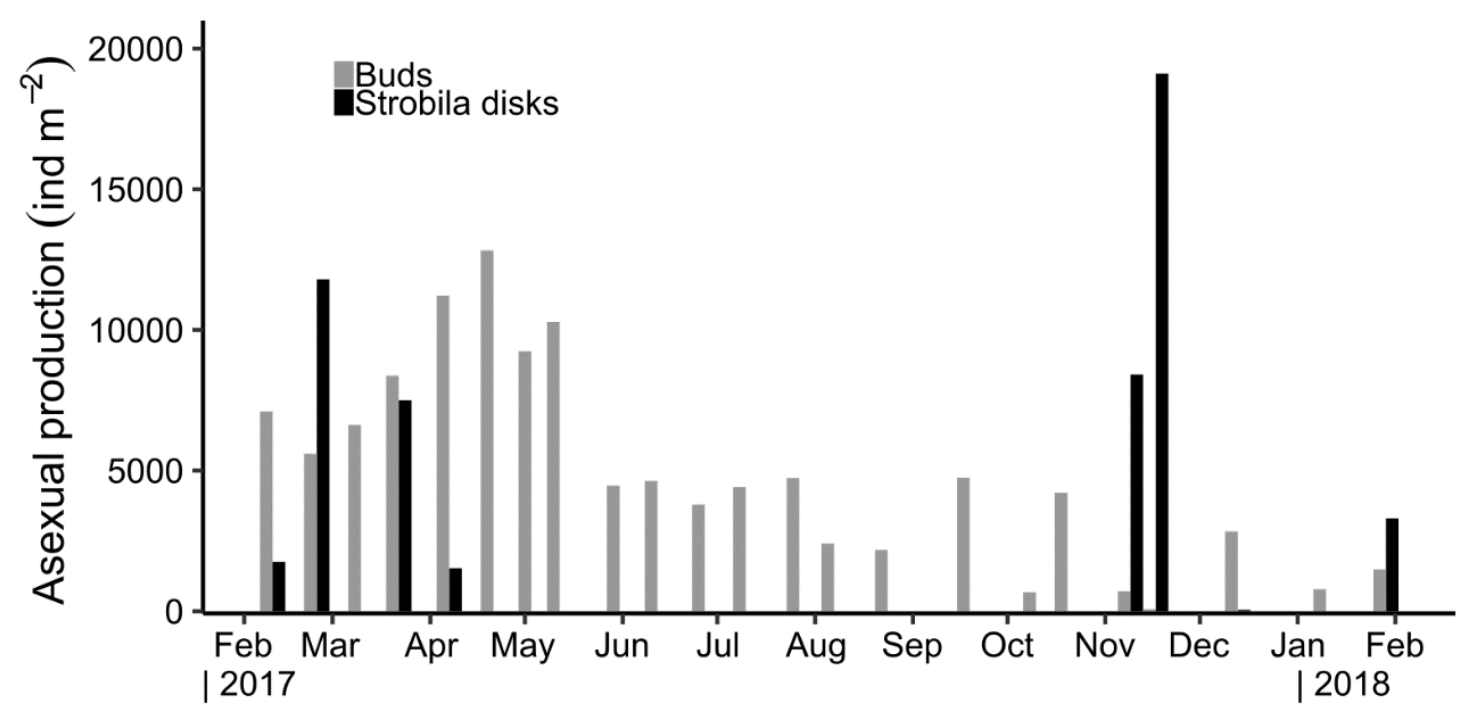

771

772 Fig. 7 Asexual Production $\left(A P_{t i}\right)$ in the Thau lagoon over the study period. Each bar represents 773 the estimated production of non-motile buds (grey) and strobila disks (black) by the population 774 of $A$. coerulea scyphistoma, at each sampling time $\left(t_{i}\right)$, at the study site

775

776

777 
Table 1 Parameters of the final General Linear Models used to assess correlations between each of the biological variables (scyphistoma coverage, percentage of scyphistomae producing nonmotile buds (NMB) and podocysts per scyphistoma) and environmental variables in the lagoon.

782 Temp: temperature $\left({ }^{\circ} \mathrm{C}\right)$, Sal: salinity; Chla: chlorophyll $a$ concentration $\left(\mu \mathrm{g} \mathrm{L}^{-1}\right), \log \mathrm{ZAb}$ : mesozooplankton abundance $\left(\ln (\mathrm{x}+1)\right.$ ind $\left.\mathrm{m}^{-3}\right)$. Significant correlations $(P<0.05)$ are indicated in bold.

\begin{tabular}{|c|c|c|c|c|}
\hline Scyphistoma coverage (\%) & Estimate & Std. Error & $\mathrm{t}$ value & $P$ \\
\hline (Intercept) & -1.78 & 1.22 & -1.46 & 0.17 \\
\hline Temp & 0.23 & 0.09 & 2.47 & $\mathbf{0 . 0 3}$ \\
\hline Sal & 0.05 & 0.03 & 1.50 & 0.16 \\
\hline $\log Z A b$ & 0.21 & 0.19 & 1.09 & 0.29 \\
\hline Temp:Sal & -0.01 & 0.00 & -2.43 & $\mathbf{0 . 0 3}$ \\
\hline Temp:logZAb & -0.02 & 0.01 & -1.62 & 0.13 \\
\hline Sal:logZAb & -0.01 & 0.01 & -1.12 & 0.28 \\
\hline Temp:Sal:logZAb & 0.00 & 0.00 & 1.62 & 0.13 \\
\hline \multicolumn{5}{|l|}{ NMB (\%) } \\
\hline (Intercept) & 179.57 & 221.44 & 0.81 & 0.42 \\
\hline Temp & -12.97 & 14.69 & -0.88 & 0.38 \\
\hline Sal & -5.32 & 5.80 & -0.92 & 0.36 \\
\hline MChla & -231.26 & 240.37 & -0.96 & 0.34 \\
\hline $\log Z A b$ & -20.53 & 28.22 & -0.73 & 0.47 \\
\hline Temp:Sal & 0.37 & 0.38 & 0.96 & 0.34 \\
\hline Temp:MChla & 13.17 & 15.31 & 0.86 & 0.39 \\
\hline Sal:MChla & 6.63 & 6.35 & 1.04 & 0.30 \\
\hline Temp:logZAb & 1.46 & 1.88 & 0.78 & 0.44 \\
\hline Sal:logZAb & 0.61 & 0.74 & 0.83 & 0.41 \\
\hline MChla:logZAb & 28.57 & 31.26 & 0.91 & 0.36 \\
\hline Temp:Sal:MChla & -0.37 & 0.40 & -0.92 & 0.36 \\
\hline Temp:Sal:logZAb & -0.04 & 0.05 & -0.86 & 0.39 \\
\hline Temp:MChla:logZAb & -1.53 & 1.99 & -0.77 & 0.44 \\
\hline Sal:MChla:logZAb & -0.83 & 0.83 & -1.00 & 0.32 \\
\hline Temp:Sal:MChla:logZAb & 0.04 & 0.05 & 0.83 & 0.41 \\
\hline \multicolumn{5}{|l|}{ Podocysts per scyphistoma } \\
\hline (Intercept) & -2.56 & 1.47 & -1.75 & 0.10 \\
\hline Temp & 0.29 & 0.11 & 2.61 & 0.02 \\
\hline Sal & 0.07 & 0.04 & 1.76 & 0.09 \\
\hline Temp:Sal & -0.01 & 0.00 & -2.54 & 0.02 \\
\hline
\end{tabular}


Table 2 Hurdle model coefficients used to assess the influence of environmental variables on

790 strobilation intensity. Temp: temperature $\left({ }^{\circ} \mathrm{C}\right)$, Sal: salinity; Chla: chlorophyll $a$ concentration

$791\left(\mu \mathrm{g} \mathrm{L}^{-1}\right), \log \mathrm{ZAb}$ : mesozooplankton abundance $\left(\ln (\mathrm{x}+1)\right.$ ind $\left.\mathrm{m}^{-3}\right)$. Significant correlations $(P<$

$7920.05)$ are indicated in bold.

\begin{tabular}{|c|c|c|c|c|}
\hline $\begin{array}{l}\text { Count model coefficients } \\
\text { (truncated negbin with log link): }\end{array}$ & Estimate & Std. Error & $\mathrm{z}$ value & $P$ \\
\hline (Intercept) & -1.79 & 11.73 & -0.15 & 0.88 \\
\hline Temp & 0.27 & 0.47 & 0.57 & 0.57 \\
\hline Sal & 0.19 & 0.30 & 0.64 & 0.52 \\
\hline Chla & 0.10 & 0.60 & 0.17 & 0.87 \\
\hline $\log Z A b$ & -0.62 & 0.89 & -0.71 & 0.48 \\
\hline $\log ($ theta $)$ & -0.19 & 0.60 & -0.31 & 0.76 \\
\hline \multicolumn{5}{|l|}{$\begin{array}{l}\text { Zero hurdle model coefficients } \\
\text { (binomial with logit link): }\end{array}$} \\
\hline (Intercept) & -2.23 & 12.40 & -0.18 & 0.86 \\
\hline Temp & -0.29 & 0.15 & -2.00 & 0.05 \\
\hline Sal & 0.08 & 0.31 & 0.24 & 0.81 \\
\hline Chla & 0.83 & 0.90 & 0.92 & 0.36 \\
\hline $\log Z A b$ & 0.23 & 0.45 & 0.52 & 0.60 \\
\hline Exponentiated coefficients & & Count model & Zero h & nodel \\
\hline (Intercept) & & 0.17 & & 0.11 \\
\hline Temp & & 1.31 & & 0.75 \\
\hline Sal & & 1.21 & & 1.08 \\
\hline Chla & & 1.11 & & 2.29 \\
\hline $\log Z A b$ & & 0.54 & & 1.26 \\
\hline
\end{tabular}

793 